\title{
Towards a progressive interpretation of $\mathrm{Ummah}^{1}$
}

\author{
Hasnan Bachtiar \\ The Australian National University (ANU), Australia \\ E-mail: u6292460@anu.edu.au \\ DOI: $10.18326 /$ ijims.v8i1.87-116
}

\begin{abstract}
This paper elaborates the discourse of the development of Ummah from various contemporary literatures that had been produced by Muslim and non-Muslim scholars and intellectuals, ranging from Muslim and Western countries. With the progressive perspective of multiple modernities and intercivilisational approach, this paper argues that the concept of Ummah should be interpreted as a modern concept of inclusive cosmopolitan-humanitarian solidarity that emphasise values of liberalism, pluralism, democracy, human rights and sustainable development. This concept has been also strengthened by a sociological representation of the tradition of Islam Nusantara. Its relative historical continuity in the process of the development of the micro sociological dimension of tradition, it explains that this concept of Ummah is not rootless. Consequently, it can be understood that its applicability is relatively possible .
\end{abstract}

Paper ini ingin mengelaborasi wacana pembangunan konsep Ummah yang digali dari pelbagai literatur kontemporer, baik yang berasal dari para sarjana dan intelektual Muslim maupun non-Muslim, baik itu yang berasal dari negara-negara Muslim maupun Barat. Melalui perspektif multiple modernities

\footnotetext{
${ }^{1}$ I would like to thanks to Professor James Piscatori, for his supervision and his invaluable inspirations during the process of research. The previous version of this paper was prepared and submitted in the examination of the course of "Islam and Democracy" in the Centre for Arab and Islamic Studies (CAIS), the Australian National University (ANU), Australia.
} 
dan pendekatan lintas-peradaban, paper ini berargumentasi bahwa konsep Ummah sangat perlu kiranya ditafsirkan dan dipahami sebagai konsep modern mengenai solidaritas kemanusiaan yang inklusif dan kosmopolitan. Konsep ini menekankan pentingnya nilai-nilai seperti liberalisme, pluralisme, demokrasi, hak asasi manusia dan pembangunan yang berkelanjutan. Adanya tawaran mengenai konsep ini, didukung oleh representasi sosiologis dari praktik Islam Nusantara. Praktik Islam Nusantara tersebut, menunjukkan adanya kontinuitas historis dalam proses pembangunan tradisi, yang berlaku di dalam dimensi sosiologis yang bersifat mikro. Hal ini tentu saja juga menunjukkan bahwa konsep Ummah ini bukanlah hal yang tak berakar dalam realitas kehidupan Muslim. Dengan demikian dapat dimengerti bahwa, penerapan konsep Ummah ini sangatlah memungkinkan.

Keywords: Progressive interpretation; Cosmopolitan Ummah; Multiple modernities; Inter-civilisational approach

\section{Introduction}

Reformulating a progressive interpretation of Ummah is not an easy task, since it inevitably should challenge social, political, cultural and theoretical complexities. On one hand, as a discourse, Ummah has been contested internally amongst Muslims from the spectrum of liberalism into conservatism. On the other hand, it has been also debated amongst intellectuals those who mainly have affiliated with the Western scholarship. Thus, Ummah in this context is just a commodity in the supermarket of complicated ideological, political and intellectual contestations.

Although it is not easy and perhaps, working on it is too ambitious, there is a chance to dive in deeper complexities, diagnose them and try to find the conceptual reflection and resolution that can be able to radically awaken the spirit of reform. Indeed this reform is critical for Muslims and the Muslim world, since they have claimed and proclaimed the ideal of the victory of Islam and Muslims ('izz al-Islam wa al-Muslimin). However, what it does mean with the victory (al-'izz) should necessarily be 
viewed neither in any narrowed dogmatic claim of the religious ideology nor certain cultural nativism.

In this task, paradigmatically, I rather agree with the conceptual point of view that offered by progressive scholars like James Piscatori, Amin Saikal and Tariq Ramadan. However this task will go further beyond them at the effort of reinventing the fresh idea of Ummah. While Piscatori emphasises the importance of "conformism" in terms of political adaptability with the modern concept of the polity of the West, ${ }^{2}$ Saikal revitalises the essential of the modern "ijtihad" rather than "jihad", ${ }^{3}$ and Ramadan disseminates the notion of the "radical reform" in dealing with the project of inseminating the global message of Islam to the current socio-cultural realm, ${ }^{4}$ I tend to engage myself in the constellation of the conceptualisation of Islam (which is Ummah) that possible to bridge an inter-civilisational dialogue and provide such a conceptual reconciliation.

Obviously, this intellectual effort owes to brilliant elaborations of Bernard Lewis's "What Went Wrong?", 5 Samuel Huntington's "the Clash of Civilizations", ${ }^{6}$ Edward Said's "Orientalism", 7 and Hassan Hanafi's "Occidentalism". ${ }^{8}$ Not only them that give primary contributions, but

2 James Piscatori, Islam in a World of Nation-States, Cambridge: Cambridge University Press, 1986, 40.

3 Amin Saikal, "Westphalian and Islamic Concepts of Sovereignty in the Middle East," in Sampford \& Thakur (eds.), Re-envisioning Sovereignty: the End of Westphalia?, London: Ashgate, 2008, 80-81.

${ }^{4}$ Tariq Ramadan, Radical Reform, Islamic Ethics and Liberation, Oxford, New York: Oxford University Press, 2009, 33.

${ }^{5}$ Bernard Lewis, What Went Wrong? Western Impact and Middle Eastern Response, New York: Oxford University Press, 2002.

6 Samuel Huntington, The Clash of Civilizations and the Remaking of World Order, New York: Simon and Schuster, 1996.

${ }^{7}$ Edward W Said, Orientalism, London: Penguin Books, 2003.

${ }^{8}$ Hassan Hanafi, Muqaddimah fi 'ilm al-Istighrab, Cairo: Dār al-Faniyyah, 1991; Hassan Hanafi, "From Orientalism to Occidentalism," Encounters in Language and Literature, 2010, 407-414. Retrieved from http://www.fortschritt-weltweit.de/dokumente/ aegypten /fortschritt_aegypten_hanafi.pdf (14 September 2017). 
also the works amongst Muslims - that actually some political scientists would like to name them Islamists - such as Sayyid Qutb's Ma'alim fi al-Tăriq' (Milestones), ${ }^{9}$ al-Maududi's 'al-Khiläfah wa al-Mulk' (the Caliph and the Empire) ${ }^{10}$ and Khomeini's "Hukumat Islamiyyah" (the Islamic Government). ${ }^{11}$ Although there is no such a perfect scholarship that is sometimes strongly influenced by both a certain political interest and an ideological tendency, their intellectual inclinations succeeded to give birth to the best and inspirational resources for self-reflection.

In this reflection, elaborating inspirational thoughts that have been unearthed from the mentioned endogenous and exogenous literatures, and applying the inter-civilisational approach, I argue that the notion of Ummah should be viewed as a modern concept of humanitarian solidarity that lies beyond boundaries of religion, nation, culture, tradition, ethnicity, race and colour. It also should be established under the umbrella of civic pluralism and universal humanism. However, it is not the concept that is rootless socially and culturally. Indeed, it can be found in certain civilisational entities both in the level of value and manifestation. In this context, the tradition of Islam Nusantara can be understood as a kind of sociological representation of the concept. In dealing with this reflection, this paper will systematically discuss the political history of the discourse of Ummah, its conceptual debates and reformulation of a modern Ummah, and its sociological representation.

\section{The political history of the discourse of Ummah}

The discourse of Ummah has rooted in the political history of Islam since the prophetic era in the $7^{\text {th }}$ century until the $21^{\text {st }}$ century. However, I

\footnotetext{
${ }^{9}$ Sayyid Qutb, Ma'àlim fí al-Tăriq, Cairo: Dār al-Syurūq, 1979.

${ }^{10}$ Abul A'la Al-Maududi, Al-Khiläfah wa al-Mulk, Kuwait: Dār al-Qalam, 1978.

${ }^{11}$ Khomeini, Islamic Government: Governance of the Jurist, Tehran: Institute for Compilation and Publication of Imam Khomeini's Work, 2002.
} 
tend to argue that the massive spreading of this discourse had happened in the 1960s-70s. It had coincided with the advent of the phenomenon of Islamic revivalism. ${ }^{12}$ In this moment, Ummah was reclaimed amongst Muslims that reactively had embraced themselves in the midst of the euphoria of socio-political revolution. ${ }^{13}$ In short, it was turning point where Muslims had imagined socially and politically "the community of believers" that united and handed by one utopian leadership. The current political and social scientists such as Olivier Roy ${ }^{14}$ and Asef Bayat ${ }^{15}$ categorise this phenomenon as Islamism that imposed by Islamists.

This momentous path in the history of Islam should be understood as a median of the ancient era - both in the time of the inception of Islam and the era of caliphates and sultanates - that links to the contemporary phenomenon of the political Islam of the Post 9/11. The idea of Ummah as the social imaginary that reclaimed by Islamists never comes without experiences of the past. However, this view should not fall into the historical determinism that results the fallacy of causal logics which is in turn essentialising the continuity of historical contents of Islam. ${ }^{16}$ Thus, this understanding actually provides a less difficult timeline that flexibly reveals some sorts of certain episodes of Islamists' political campaigns over the discourse of Ummah.

In this path, there are three central points in three different episodes

${ }^{12}$ Armando Salvatore, The Sociology of Islam: Knowledge, Power and Civility, Malden, MA: Willey Blackwell, 2016, 5.

${ }^{13}$ James Piscatori, "Reinventing the Ummah? The Trans-locality of Pan-Islam," Lecture to the Tenth Anniversary Conference: Translocality: An Approach to Globalising Phenomena, Zentrum Moderner Orient, Berlin, 26 September 2006, 7-12; James Piscatori, "Imagining Pan-Islam," in Shahram Akbarzadeh and Fethi Mansouri (eds.), Islam and Political Violence, London; New York: IB Tauris, 2014, 27-38.

${ }^{14}$ Oliver Roy, The Failure of Political Islam, London; New York: IB Tauris, 1994, 37.

${ }^{15}$ Asef Bayat, Life as Politics: How Ordinary People Change the Middle East, Second Edition, Stanford, CA: Stanford University Press, 2013, 68.

${ }^{16}$ Talal Asad, Genealogies of Religion: Discipline and Reasons of Power in Christianity and Islam, Baltimore; London: John Hopkins University Press, 1993, 29. 
IJIMS: Indonesian Journal of Islam and Muslim Societies, Volume 8, Number 1, June 2018: 87-116

that perhaps can be underlined regarding the effort of politicizing the discourse of Ummah. The first is the notion of 'al-urwa al-wuthqa' (the tight bond) that promoted by Jamal al-Din al-Afghani (1839-1897) and Muhammad 'Abduh (1849-1905); the second is the communitarian idea of Islamic nationalism that endorsed by Sayyid Qutb (1906-1966), Abu al-A'la al-Maududi (1902-1979) and Ayatollah Khomeini (1902-1989); the third is the universalist-totalitarian notion of Islamic state that sponsored by Hizb al-Tahrir (the Liberation Party) (1953-) and the Islamic State of Iraq and Syria (ISIS) (2003-).

They all interpret Ummah in various ways of world view, ideological tendency, methodology and political interest, depend on socio-politico-cultural factors that shape around them. The first, in order to develop Ummah, al-Afghani and 'Abduh perceive that Muslims need a reform in terms of education. ${ }^{17}$ When they control the education of the youth, they will be able to ensure that the next Muslim generation will be the best social and political agencies that bring the Islamic resurgence. ${ }^{18}$ Here, it is the meaning of the tight bond of Islam. The second, Qutb, al-Maududi and Khomeini - with each specificity and peculiarity - promotes that the best Ummah will be established if they work together with the identity as Muslims - that declare the 'syahadatain' (believe in Allah and Muhammad is the messenger of God) - to solve any social and political problem in a certain national boundary of Muslim country. ${ }^{19}$ They also emphasise the implementation of sharia law that integrated in the system of the state.

\footnotetext{
${ }^{17}$ Sami Abdullah Kaloti, The Reformation of Islam and the Impact of Afghani and Abduh on Islamic Education, Doctoral Dissertation, Marquette University, Wisconsin, 1974.

${ }^{18}$ Kaloti, The Reformation of Islam and the Impact of Afghani and Abduh on Islamic Education; Indira Falk Gesink, "Islamic educational reform in Nineteen Century-Egypt: lessons for the present," in Charlene Tan (ed.), Reforms in Islamic Education: International Perspectives, London; New York: Bloomsbury Academic, 2014. 17-34.

${ }^{19}$ Sayyid Qutb, Ma'älim fi al-Ṭāìq, 24; Abul A'la Al-Maududi, Al-Khiläfah wa al-Mulk, 37; Khomeini, Islamic Government: Governance of the Jurist, 18-28.
} 
The third, Hizb al-Tahrir and ISIS claims that the enlightenment of Islam and Muslim Ummah will appear if the political power of the world controlled and governed by the caliph of the global caliphate. ${ }^{20}$. While the former moves in the non-violence political expansion, the latter (particularly ISIS) entirely plays the role of the strategy of violence in its political manoeuvres.

However, their interpretation on the concept of Ummah remains unclear. The shape of Ummah is never completely fixed, although they have a social imaginary on the idea of "the community of believers". While al-Afghani and Abduh rather understand that Ummah is the concept of the ideal 'Islamic community', Qutb, al-Maududi and Khomeini tend to view that Ummah is the national identity of Muslim and the autonomous Islamic state. It is not quite different from their opinion, in addition, other groups, religious movements and political parties such as "al-Ikhwan al-Muslimin" (Muslim Brotherhood) in Egypt, Jamaat-i-Islami (the Islamic Society) in Pakistan, Front Islamique du Salut (the Islamic Salvation Front) in Algeria and many others tend to understand that Ummah relatively either as a "society", "state" or "group of political elites" in the sense of the oligarchic-partitocracy. ${ }^{21}$ Moreover, Hizb al-Tahrir and ISIS imagines

\footnotetext{
${ }^{20}$ It is not quite clear whether the ISIS assertion of the global Ummah is just an ideological rhetoric. In fact, the ISIS leader, Abu Bakr al-Baghdadi in several times had emphasised the establishment of the Islamic caliphate state of Iraq and Syria. It means, it had been limited in a boundary of state level, not the global-transnational level. Hence, there has been such inconsistency for this group in dealing with their concept of Ummah. Peter Mandaville, Global Political Islam, London; New York: Routledge, 2007, 266; Reza Pankhurst, The Inevitable Caliphate?: A History of the Struggle for the Global Islamic Union, Oxford; New York: Oxford University Press, 2013, 99-130; Carlos Alberto Torres, Theoretical and Empirical Foundations of Critical Global Citizenship Education, London; New York: Routledge, 2017, 154.

${ }^{21}$ Sami Zubaida, "Islam and Nationalism: Continuities and Contradictions," Nations and Nationalism, vol. 10, no. 4 (2004), 407-420; Ranko, The Muslim Brotherhood and its Quest for Hegemony in Egypt: State-Discourse and Islamist Counter-Discourse, New York: Springer, 2015; Islam, Jamaat-e-Islami in Contemporary India and Bangladesh, Delhi: Cambridge University Press, 2015; Shahin, "The Foreign Policy of the Islamic Salvation Front in Algeria," Islam
} 
that Ummah is the transnational or the global Islamic state. Uniquely, all of them are intrumentalising the idea of Ummah and sometimes interchangeably campaigning the jargon of 'Pan-Islamism', or the socio-political advocacy for the establishment of Ummah. ${ }^{22}$

Therefore, according to this history, the notion of Ummah can be understood conceptually as the "community of believers" that is relatively delimited either by sociological, national-political or transnational-political boundaries. Its boundaries depend on political players that have certain political tendencies and inclinations.

\section{Conceptual debates}

In this part, I am questioning the concept of Ummah that is popularly presented both by Muslim intellectuals and Western scholars, since they are unlikely offering any conceptual breakthrough that can contribute to help solving problems. ${ }^{23}$ It is imperative to deliver a critical evaluation of concepts that are quite distant from the "work(s) that could lead or transform a particular religion towards unfolding its best potentials for mankind." 24 Thus, in this context, the concept of Ummah should be functionalised to strengthen vitality of life not only amongst Muslims, but also all religious believers and non-believers (humanists).

Perhaps, there are two primary problems that can be simplified in the Middle East. The first is the cultural problem at bundling a set of arguments and practices in the micro level societal dimension amongst Mus-

\footnotetext{
and Christian-Muslim Relations, vol. 14, no. 2 (2003), 121-143.

22 James Piscatori, "Reinventing the Ummah? The Trans-locality of Pan-Islam."; James Piscatori, "Imagining Pan-Islam."

${ }^{23}$ Burke, "Orientalism and World Wistory: Representing Middle Eastern Nationalism and Islamism in the Twentieth Century," Theory and Society, vol. 27, no. 4 (1998), 489-507.

${ }^{24}$ Ibrahim, "The Making of Progressive Religion," in Azhar Ibrahim and Mohamed Imran Mohamed Taib (eds.), Islam, Religion and Progress, Singapore: The Reading Group Singapore, 2006, 1.
} 
lims as social agencies. They, commoners, intellectuals and structural leaders, find it difficult to provide knowledge production and pattern of communication that inherently can be excavated from religious values of Islam. They supposedly fail to play the role of a progressive interpretation on Islam. Islam is rarely viewed as the religion of progress that is able to urge the process of socio-economic and political development (it is not in the sense of Weberian reformism of the "Protestant Ethics and the Spirit of Capitalism", but with their own specificities and peculiarities). ${ }^{25}$ The second is the structural problem that grips themselves and brings into the backwardness and the massive public suffering. This structural problem internally comes from the country itself which means authoritarian leadership and despotism, ${ }^{26}$ and externally it is weighed by the economic and political expansion of the Western imperialism. ${ }^{27}$

In the midst of this critical situation with its complexities, as a consequence, almost there is no factual evidence that shows intellectual efforts that can ensure the best process of conceptualisation over the discourse of Ummah. Historically, the expanding idea of Ummah has coincided with the intensifying of the reactionary defiance amongst Muslims against regimes of dictatorship and imperialists.

In dealing with this evaluation, the case of an Egyptian Islamist leader, Sayyid Qutb is very influential to be discussed. In his influential work

${ }^{25}$ Max Weber, The Protestant Ethic and the Spirit of Capitalism, London: Routledge, 2001; Bryan S Turner, Weber and Islam: A Critical Study, London: Routledge and Kegan Paul, 1974; Armando Salvatore, "Tradition and Modernity within Islamic Civilization and the West," in Muhammad Khalid Masud, Armando Salvatore and Martin van Bruinessen (eds.), Islam and Modernity: Key Issues and Debates, Edinburgh: Edinburgh University Press, 2009, 4; Armando Salvatore, The Sociology of Islam: Knowledge, Power and Civility, Malden, MA: Willey Blackwell, 2016, 4-5.

${ }^{26}$ Karakoç, Authoritarianism in the Middle East: Before and After the Arab Uprisings, Hampshire: Palgrave Macmillan, 2015.

${ }^{27}$ Brown, "New Wine, Old Bottles," in International Politics and the Middle East: Old Rules, Dangerous Game, London: IB Tauris, 1984, 85-167. 
Ma'älim fĩ al-Ṭăriq (Milestones), he provocatively encouraged Muslims to perceive that the West, its power, political manoeuvre and civilisation are the real enemy that cause public suffering. He also criticised the national leadership of the President of Gamal Abdul Nasser that was allegedly over dependent on the imperialist politics. He claimed that the Islamic world (primarily is Egypt) needs a leadership that is able to embrace the Islamic Ummah. He mentioned that "wa läbudda min qiyādah li al-bashariyyah jadidah!" (It is essential for mankind to have new leadership). ${ }^{28}$

It is well-known that Qutb was living in the context of intimidation, coercion, criminalisation and torture by the regime of Nasser. He, himself was accused of subversion (plotting the assassination of Nasser) and executed in 1966. It cannot be doubted that his conceptualisation of Ummah, was coloured by this vulnerable situation of dehumanisation. ${ }^{29}$ Accordingly, his concept of Ummah was actually born from the womb of the ideology of detestation, misery and vengeance. Obviously, his concept seems unlikely to be considered as the kind of the progressive interpretation, since it was based and developed from the resentment ideology.

Possibly the Qutb's case is an extreme political history of Muslim intellectualism. Other cases that relatively have similar patterns though with different angles, contexts and moments occurred. The historical episodes of Afghani and Abduh, al-Maududi and Khomeini, and Hizb al-Tahrir and ISIS are strongly can be considered here. They understand that Islam is a universal religion that is immutable in a totalitarian sense. In the critical view, this understanding brings into the stagnation, decadence and far away from the sense of progress, reform and transformation. ${ }^{30}$ They

\footnotetext{
${ }^{28}$ Sayyid Qutb, Ma'äim fí al-Tăriq..., 3.

29 Brykczynski, "Radical Islam and the Nation: The Relationship between Religion and Nationalism in the Political Thought of Hassan al-Banna and Sayyid Qutb," History of Intellectual Culture, vol. 5, no. 1 (2005).

${ }^{30}$ See Chapter 4 and 5, Piscatori, Islam in a World of Nation-States, Cambridge: Cambridge University Press, 1986.
} 
also have to carry on heavy burdens of resentment ideology that shaped by the history of human misery.

What happens in the Middle East, becomes an object of intellectual interpretations amongst Western scholars or those who that involve in the scholarship activity in the West. Bernard Lewis and Samuel Huntington for example, with different tools of analysis but still at quiet similar viewpoint, they tend to argue that Islam is a cultural resistance that prevents socio-political and economic development. ${ }^{31}$ At the same time, they also understand that Muslims have been living in the culture of "oriental despotism" that blocks liberal freedom, secularism and democracy. They indeed never have the life experience as same as that hardly felt by Muslims. Accordingly, they claim that there is something wrong with Islam due to its contradictions with the civilisational vitality of the Western enlightenment. For them, Islam is absent from the central ideal of modernity.

Against this over-simplified view of Lewis and Huntington, Edward Said $^{32}$ and Hassan Hanafi ${ }^{33}$ offer critical examinations that emphasise that Orientalists and Western social scientists have worked under biases of the superiority of the Western modernism. They deliberately express their intellectual responses to "pseudo-scholarship" works of Orientalism that vocalised to the public in order to support projects of colonialism and imperialism. It is important to appreciate Said's and Hanafi's argument. However they do not offer - borrowing terms from a sociologist, Armando Salvatore - an "intellectual trajectory" and "reflexive turn" to attempt to diagnose critically both sides Muslims and Western scholars. ${ }^{34}$

\footnotetext{
${ }^{31}$ Bernard Lewis, What Went Wrong?; Samuel Huntington, The Clash of Civilizations.

${ }^{32}$ Edward Said, Culture and Imperialism, London: Vintage, 1994; Edward Said, Orientalism, London: Penguin Books, 2003.

${ }^{33}$ Hassan Hanafi, Muqaddimah fi 'ilm al-Istighrab, Cairo: Dār al-Faniyyah, 1991; Hassan Hanafi, "From Orientalism to Occidentalism," 2010.

${ }^{34}$ Armando Salvatore, The Sociology of Islam..., 1.
} 
It means that there is no conceptual breakthrough at opening the inter-civilisational dialogue. What they offer is only criticism. While in his "Covering Islam" ${ }^{35}$, Said still plays the role of post-colonialist critic of Orientalism, Hanafi's "Occidentalism" 36 drives totally a similar style of criticism. At length Hanafi's note is aptly to discuss here:

"Orientalism is born in an ethno-racist culture. It expresses Eurocenterism, based on historical pride and organic superiority. This pits White against Black, knowledge against ignorance, logic against contradiction, reason against magic, rationalization against ethico-religious practice, dignity and human rights against dignity and rights of God or of the king, democracy versus despotism or in short, Life against death, Being against nothingness. Occidentalism corrects this type of relationship between the West as Self and the Orient as Other to the Orient as self and the West as Other. The relation between the self and the Other, either way, can be an equal relation, not a high-low relation, an even and sane inter-subjective relation instead of a superiority-inferiority complex. Constructive Occidentalism is the substitute for destructive Orientalism." ${ }^{37}$

At the same side, I totally disagree with a critical examination on the Lewis's and Huntington's works. However, it is important to give an appreciation of their efforts in uncovering complicated problems of the Muslim leadership that are coloured by the history of authoritarianism, despotism, dictatorship and terror. Thanks to the project of the Western modernism that helps to scrutinise some sorts of internal obstacles of the development of Muslim countries.

Therefore, both Muslim intellectuals and Western scholars still find it difficult to make an intellectual reconciliation in terms of the inter-civilisational dialogue. They have been trapped in the game of the reciprocal oppression, subordination and marginalisation. While Muslims inferiorly have played victims, Western scholars have indicted the black sheep. In

\footnotetext{
${ }^{35}$ Edward Said, Covering Islam, London: Vintage, 2007.

${ }^{36}$ Hanafi, Muqaddimah fi 'ilm al-Istighrab; Hanafi, "From Orientalism to Occidentalism."

${ }^{37}$ Hanafi, "From Orientalism to Occidentalism"..., 8-9.
} 
this context, the conceptualisation of the discourse of Ummah has been congested by endless interests that disregard the virtue of humanisation.

\section{Reformulation of a modern Ummah}

In this part, there is necessity to reformulate the progressive concept of Ummah. This concept should encompass and embrace an idea that reaches beyond the current contemporary discourse that is trapped in the locked stymie. It means, this concept should be able to provide a way out from problems and urge to the development of inter-civilisational dialogue. In this way, Islam and the West should be viewed in an equal position as an opened civilisational corpus that can be interpreted and potentially contains extraordinary virtues, ethical values and spirits of life. Consequently, the concept of Ummah should be elaborated with the most current and sophisticated contemporary political ideas of the West which are liberal, secular, pluralist, democratic and honouring values of the universal humanism. Ummah in this comprehension should be supported by socio-humanistic pillars of liberalism, pluralism, democracy, human rights and sustainable development. Hence, the concept of Ummah should be reinvented as the modern concept of humanitarian solidarity, beyond the boundaries of religions, cultures, nations, traditions, ethnicities, races and colours.

This reformulation owes to inspirational ideas of reform amongst scholars such as Tariq Ramadan, Amin Saikal and James Piscatori. Ramadan initiates the idea of reform that should be unearthed not only from the Islamic tradition, but also the modern Western tradition. ${ }^{38}$ It means that Muslims should rethink their own critical consciousness and self-criticism, rich philosophical and theological sources and their involvement in the process of the development of inter-civilisational dia-

\footnotetext{
${ }^{38}$ Ramadan, Radical Reform, Islamic Ethics and Liberation..., 37.
} 
logue. At the same time, it is also essential to develop their critical tradition which means critical thinking and rationality that very accentuated in the prophetic era. All these matters, according to Saikal, in Islamic terminology called "ijtihad" ${ }^{39}$ However, it should be distinguished with a conventional ijtihad that cannot liberate itself from its over dependence on the less rational thought and imitativeness (taqlid). In this context, actually Muslims have a great opportunity to develop their own civilization and inclusively a common human civilisation. In addition, Piscatori states that politically they also have special characteristics that conformist, which means "accommodate themselves to the political reality" 40 that emphasises the essentials of the intra-civilisational and inter-civilisational development. Thus, in conceptualising the idea of Ummah, the basis of the spirit of reform cannot be denied.

One of the important efforts of the critical diagnosis of the concept of Ummah has been conducted by Nazih Ayubi. He also implicitly in his "Over-Stating the Arab State" (1995) offers such a starting point to understand the complicated problems that should be challenged. In this work, Ayubi presents a comprehensive report on the concept of Islamic Ummah and Arab states that Muslims have, which are anti-Western, anti-enlightenment and anti-modernism. ${ }^{41}$ Muslims' concept of the state is rather the colonial legacy, pre-mature and "its legality constraints the development towards becoming real sociological states." ${ }^{42}$ Arab states have neither sufficient infrastructural power, nor the ideological hegemony that ensures the forging of their historical and social bloc. They also do not have the philosophical concept of individualism and social classes in

${ }^{39}$ Saikal, "Westphalian and Islamic Concepts of Sovereignty in the Middle East"..., 81.

${ }^{40}$ Piscatori, Islam in a World of Nation-States..., 40.

${ }^{41}$ Nazih Ayubi, Over-Stating the Arab State: Politics and Society in the Middle East, London; New York: IB Tauris, 1995, 16-17, 21-24.

${ }^{42}$ Nazih Ayubi, Over-Stating the Arab State..., 12. 
the sense of capitalist societies. They, in Ayubi's view, are states of étatism which means "the populist regimes try to pursue development and welfarist policy at the same time." ${ }^{43}$

At facing this reality, for Ayubi, if Ummah can be defined as the state, so ideally, it should be transformed into the modern concept of the Western state. However realistically, it is important to offer a conceptualisation that "mediates" the actual form of rentierist étatisme (some of them are also consociationalist) of the Arab states with the concept of the modern state: corporatism. ${ }^{44} \mathrm{He}$ argues that "in societies where theoretical individualism is weak and where classes are embryonic, neither the conventional liberal nor the conventional Marxist paradigms seem to able to capture the realities of the situation." ${ }^{45}$ He tries to ensure political efforts that persistently "search for intermediaries that can bind the individual and the groups to the state." ${ }^{46}$ The corporatism will be functioned as the bridge for the state and society, or the public and the private.

However, the concept of Ummah that will be offered here is not limited to the concept of the state. It does not mean that Ayubi's reformulation is not important, though academically it is widely open to be debated. The prescriptive form of corporatism should be understood as a first stage of realistic projects that gradually can be developed and transformed into the ideal form of the modern state. What does mean with the new reformulation of the concept of Ummah is not only merely an abstract concept of the global level of the human and humanitarian development. It also reaches out the affirmation of the autonomous development of nation states. Philosophically, Ummah is an umbrella of humanism that interconnectedly pervades various borders of identity, politics and territory.

\footnotetext{
${ }^{43}$ Nazih Ayubi, Over-Stating the Arab State...,3.

${ }^{44}$ Nazih Ayubi, Over-Stating the Arab State..., 33-35.

${ }^{45}$ Nazih Ayubi, Over-Stating the Arab State..., 33.

${ }^{46}$ Nazih Ayubi, Over-Stating the Arab State..., 34.
} 
IJIMS: Indonesian Journal of Islam and Muslim Societies, Volume 8, Number 1, June 2018: 87-116

Yet, sociologically, this abstract thing can be progressively urged to the societal development in the context of the micro-sociological dimension of society that affirms Islam as a dynamic and progressive cultural tradition. Islam is rather to be viewed as an ensemble of arguments and practices that facilitates patterns of communication and production of knowledge amongst Muslims to guarantee their certain social cohesions and relations. ${ }^{47}$ As a consequence, this micro-development will support the civilising process in the broader national level of the nation states. The intra and inter-state development will bring some sorts of transformation in the global world.

To build an integrated-interconnected bridge of the micro, macro and global dimension of the development of Ummah, it needs common values that mutually can be inter-shared, assimilated and fulfilled. Islam in this context, indeed, should be interpreted as the religion that emphasises virtue and righteousness, encourages progressive changes and transformations. Thus, the "Islamic state" is the state that respects substantive values of the opened corpus of Islam, not the legalisation or formalisation of the political ethics. In spite of the fact that some Muslims tend to claim that the implementation of Sharia is the best solution of societal problems, they never consider that Sharia itself is actually not the blessed elixir that revealed from the heaven. Sharia is only an inspirational source of the moral ethics and the way of search for the meaning of life. A failure to understand Sharia and desire for manipulating it, will only make religion as an instrument of a certain interest that disregards the importance of the inter-civilisational development of the future. Thus, the development

${ }^{47}$ Habermas, The Theory of Communicative Action, vol. 2, Lifeworld and System: A Critique of Functionalist Reason, Boston: Beacon Press, 1987; Doody, "Maclyntre and Habermas on Practical Reason,” American Catholic Philosophical Quarterly, vol. 65, (1991), 143-158; Salvatore, The Public Sphere: Liberal Modernity, Catholicism, Islam, New York: Palgrave Macmilan, 2007; Salvatore, "Tradition and Modernity within Islamic Civilization and the West." 
of an alternative modernity that stands side by side with the established Western modernity and other modernities is really crucial. It cannot be doubted that it should be framed in the viewpoint of multiple modernities or global modernity that is inclusive and very fluid. ${ }^{48}$

I argue that the inter-civilisational pillars of Ummah are liberalism, pluralism, democracy, human rights and sustainable development. They can also actually be functionalised as a cultural and intellectual link between "the cultural resistance of Islam" to the modernity and the political despotism and biases of the superiority of "the Western modernism viewpoint". In another world, it can be a bridge that links the creed of "Islamic universalism" amongst conservative Muslims (and also Islamists) to the Western modern enlightenment.

The first, liberalism is essential values that are not only needed in the political realm but also in all aspects of human life. Liberalism means an affirmation of values that gives larger spaces and opportunities to human freedom in the sense of individual autonomy. ${ }^{49}$ It "wherein lies the importance of Muslim society in responding to and anticipating the stagnation as well as the monopoly of religious thought which as resulted in the disruption of an intellectual revolution." ${ }^{50}$ The second, pluralism is an affirmation of values that provides conducive chances of the fertility of the growth of the inclusive co-existential relations amongst different individuals and societies and/or communities with their different identities. ${ }^{51}$ It signifies the maturity of practices of tolerance and the developed

\footnotetext{
${ }^{48}$ See Elias, The Civilizing Process, Oxford: Blackwell, 1982.

49 Abdurrahman Wahid, Islamku, Islam Anda, Islam Kita: Agama Masyarakat Negara Demokrasi, Jakarta: The Wahid Institute, 2006, 149; Ahmad Syafii Maarif, Islam dalam Bingkai Keindonesiaan dan Kemanusiaan: Sebuah Refleksi Sejarah, Bandung: Mizan, 2009, 165.

${ }^{50}$ Azhar Ibrahim, Contemporary Islamic Discourse in the Malay-Indonesian World: Critical Perspectives, Petaling Jaya: SIRD, 2014, 197.

${ }^{51}$ Nurcholish Madjid, Islam, Doktrin dan Peradaban, Jakarta: Yayasan Waqaf Paramadina, 1992; Nurcholish Madjid, "Islamic Roots of Modern Pluralism: Indonesian Experience," Studia Islamika Journal of Islamic Studies, vol. 1, no. 1 (1994), 55-77; Abdurrahman Wahid,
} 
progressive civility. The third, democracy is a socio-political affirmation of norms and values that supports the development of the "civil liberty". ${ }^{52}$ It provides an equilibrium of the sharing power in various political and governmental systems between the state and the society that respects to the supremacy of the people sovereignty and essentials of the civility. The fourth, human rights are ethical norms or principles that draw the rights that inherently adhere to individual due to he/she is a human. In this term, principles of human rights that are denoted here, refer to the modern international law of human rights, such as the Universal Declaration of Human Rights and other covenants on certain particular rights..$^{53}$ The fifth, the sustainable development is social, political, economic and cultural developments as well as human developments that respect to the values of humanity, civility, justice and equality, and the natural environment. ${ }^{54}$ It emphasises the development of the fair competition of the goodness amongst individuals or other actors that respects to values of the universal humanism.

Therefore, the micro, macro and global Ummah in the level of community/society, the state and the global world will only be possible, if they are supported by the five pillars of liberalism, pluralism, democracy, human rights and sustainable development. This reformulation will ensure the concept of Ummah as the modern concept of humanitarian solidarity.

Islamku, Islam Anda, Islam Kita, 350; Ahmad Syafii Maarif, Islam dalam Bingkai Keindonesiaan dan Kemanusiaan..., 166, 278.

52 Tocqueville, Democracy in America, Indianapolis: Liberty Fund, 2010; Nurcholish Madjid, Cendekiawan dan Religiusitas Masyarakat, Jakarta: Pramadina, 1999, 140; Nurcholish Madjid, Demokrasi dan Demokratisasi, Jakarta: Paramadina, 1999, 132; Abdurrahman Wahid, Islamku, Islam Anda, Islam Kita..., 44; Ahmad Syafii Maarif, Islam dalam Bingkai Keindonesiaan..., 147.

${ }^{53}$ Nurcholish Madjid, The True Face of Islam: Essays on Islam and Modernity in Indonesia, Jakarta: Voice Center Indonesia, 2003, 239, 273; Abdurrahman Wahid, Islamku, Islam Anda, Islam Kita..., 126; Ahmad Syafii Maarif, Islam dalam Bingkai Keindonesiaan..., 154.

${ }^{54}$ Ahmad Syafii Maarif, Islam dalam Bingkai Keindonesiaan..., 214. 


\section{A sociological representation}

One of sociological representations of the ideal notion of Ummah could be found relatively in the discourse of Islam Nusantara, though it is not without limitations. Islam Nusantara itself is a set of ensembles of essential concepts, arguments and practices of universal Islam that has been manifested in certain socio-cultural epochs of Nusantara society. ${ }^{55}$ In considering this concept, for instance, a Muslim intellectual and prominent litterateur, Mustofa Bisri rhetorically states that "The world has been questioning Islam that is graceful for the universe, Islam that is friendly, peaceful and calm, they (many people) can find it from our Islamic behaviour in this Nusantara archipelago." ${ }^{56}$ Indeed, mentioning this discourse would open further conceptual debates of whether this concept precisely represents the cosmopolitan-pluralist Ummah or does not. The conceptual debates of this discourse will cover the contemporary issues religion and society, such as compatibility between Islam and modern concepts of polity, cultural nativism and Islamic universalism, diversity and cultural manifestations of Islam, and also dynamisations and instrumentalisations of religion.

In dealing with this discourse, perhaps, it has been quite difficult to find the conceptual engagements between two notions: Islam Nusantara and the modern concepts of polity. While the former should face uneasily conceptual challenges of liberalism, pluralism, democracy, human

\footnotetext{
55 Since the idea of Islam Nusantara has been contested, there is no such fixed definition, mainly that is viewed in the socio-historical perspective. However, there is an important work that shows us more obvious understanding of it. See Akhmad Sahal and Munawir Aziz (ed.), Islam Nusantara: Dari Ushul Fiqh Hingga Konsep Historis, Bandung: Mizan, 2015, 9.

${ }^{56}$ Bisri's articulation of Islam Nusantara, originally emphasises that, "Dunia yang kemudian bertanya-tanya tentang Islam yang rahmatan lil alamin, Islam yang ramah, damai dan teduh pun mendapatkan jawaban dari perilaku keislaman kita yang di nusantara ini." See Mustofa Bisri, "Sambutan: Islam Nusantara, Makhluk Apakah Itu?" in Akhmad Sahal and Munawir Aziz (ed.), Islam Nusantara..., 14.
} 
rights and sustainable development, the latter would be difficult to base their philosophical foundations on the viewpoint of Islamic universalism. This difficulty would be intensified with assumptions of the superiority of viewpoint of the Western modernism that undermine other perspectives of multiple modernities and more inclusive inter-civilisational dialogues. In addition, in the side of the societal tradition of Islam, there is a kind of rejection that has been motivated by the conceptual simplification of the exclusive idea of Islamic universalism. In this part, Islam should be viewed as religion that is neither comparable nor compatible with other humans' ideas. Islam is perfect and greater divine sources that have been bestowed by God, while humans' ideas are inseparable from imperfections. In short, these two sides of one coin of difficulty show that Islam Nusantara seems to be unlikely the representation of the ideal notion of Ummah.

However, the argument of conceptual engagements should not be rootless. Islam Nusantara as the product of the certain societal tradition, indeed, has long-history of its establishment and development. It covers the history of inter-civilisational elaborations as well that have involved Islam, Nusantara and the Western modernism. It means, the conceptual elaborations should not eliminate the facts of the social epoch of Islam Nusantara that strongly rooted in the Nusantara society. Islam that came from the Middle East - which had been also reached by the Greco-Hindi-Irano and Semitic cultural values and traditions - culturally had merged with Nusantara multicultural characters, then during the period of $19^{\text {th }}-21^{\text {st }}$ this blended set of ensembles of arguments and practices has naturally elaborated the contemporary Western notions of polity. As a consequence, the inward-looking viewpoint of both superiority of the modernism of the West and the exclusive Islamic universalism could no longer be considered as strong and valid arguments. Such undeni- 
able evidence that supports the argument of the compatibility between Islam Nusantara and the Western modern ideas of polity is Pancasila, the Indonesian constitutional principles. Pancasila itself was claimed by its founding fathers of the Republic of Indonesia such as Soekarno, Moh. Hatta, Ki Bagoes Hadikoesoemo and others. ${ }^{57}$ Accordingly, it was inherently Islamic. In addition, it has been recognised as the inter-civilisational product of various inclusive traditions that respect to the values of divinity (ketuhanan), humanism and human rights (kemanusiaan), pluralism and nationalism (keragaman dan persatuan), democracy (kerakyatan), justice (keadilan), liberalism (kemerdekaan), development and cooperation (pembangunan dan gotong-royong).

Although, there is a socio-historical argument of the compatibility between Islam and the Western modernism in the context of Islam Nusantara, it remains internal oppositions in the Muslim circles of the region. The strongest opposition views this discourse from more conservative perspective, which states that Islam Nusantara should be not only criticised but also rejected, since it disregards the concept (or assumption) of Islamic universalism, undermines theological creeds (akidah) and tends to be claimed as an innovation (bid'ah). ${ }^{58}$ In another word, Islam should be viewed as the purified religion that cannot be subdued by any cultural penetration. Although it cannot be doubted that the manifestation of this abstract notion of Islamic universalism would never be happened (or achieved) due to it contradicts the nature of history. It means, there are always different dimensions of Islam that explain a more abstract thing of the notion of Islam that exists in the level of value, different interpreta-

57 Anhar Gonggong, Menengok Sejarah Konstitusi Indonesia, Yogyakarta: Ombak dan Media Presindo, 2002.

${ }^{58}$ Ayip Syafruddin, "Manhaji: Betapa Indahnya Nusantara Kita, Bila...” Asy-Syariah: Khazanah Ilmu-Ilmu Islam, Vol. 10, No. 112 (2016), 5-11; See also chapter "Kajian Utama: Islam Nusantara”..., 12-46. 
tions and understandings of the value(s) of Islam, and manifestations of Islam in the forms of cultural expressions. However, the exclusivity of the argument of Islamic universalism is obviously understandable due to this perspective has been constructed by the scriptural religious ideologies. There is a primary requirement of accepting this notion of Islam, such as negating other ideas that opposes ideologies of scripturalism. In Sunni Islam, for example, this argument has been developed well in the circle of various Wahhabi groups. Following this perspective, consequently, the realities of cultural manifestations of religion such as in the case of Islam Nusantara, are claimed as the phenomena of cultural nativism that constrain the existence of Islamic universalism in more totalitarian sense. Actually while the Islamic universalism supporters implement this logic of the negation of the cultural nativism, they have been trapped in the same hole by themselves. Meaning, the Islamic universalism is essentially is a kind of a cultural nativism as well. Thus, a main weakness of the ideological foundation of the notion of the Islamic universalism, its argument philosophically has been constructed by a logic that is highly potentially contradictory.

By the formulation of the previous historical argument, it can be understood that Islam Nusantara is not rootless. In another word, it has been manifested materially by various cultural forms of expressions. For example, learning from the story of Wali Songo (the Nine Saints Islam), they have been recognised by good Muslims that had proselytised Islam to Nusantara society with very peaceful ways. More or less, this wisdom has been learned and in turn adopted by the next generation of Muslims. This wisdom has counted for an essential part of tradition. In more practical level, this wisdom will bring Nusantara Muslims should not commit in certain violent actions, military aggressions and even waging war. In more simplified word, Nusantara Muslims are different with Arab 
Muslims with all of their cultural (and also societal and political) expressions that sometimes have been coloured by complex situations of conflicts and war. However, the notion and expression of Islam Nusantara, should not be viewed as a fixed and static thing. Indeed, it has been always in a persistent dynamic process and form. It has influenced and been influenced by dynamic tradition. It depends on qualities of social bonds and cohesion. Meanwhile, these qualities have been determined by arguments and practices that are motivating social agents to guarantee matters of social and communicative actions, and also cultural and institutional innovations. Indeed, as a consequence, examining the notion of Islam Nusantara does not mean to elevate one thing and undermine another, but to try to understand, examine and prove whether Islam $\mathrm{Nu}$ santara is a kind of cultural and sociological representation of the notion of ideal Ummah, or not, and whether this concept of Ummah, can be represented in a certain society with their certain historical epoch. Thus, it is quite far from a kind of philosophical debate of both the concept of cultural nativism and Islamic universalism. Islam Nusantara is a matter of socio-cultural and historical representation.

In the micro sociological dimension of tradition, Islam Nusantara as bundled templates of arguments and practices, has motivated social agents to dynamically action via certain patterns of communication and understanding. On one hand, it would ensure the process of the constitution of social relations and transformations which remains the continuity of its ideal values (the wisdom of Islam Nusantara). On the other hand, it would also open possibilities of the emergence of certain changes and directions, either in harmonic ways that need certain adaptations and reforms which reflect some degree of the continuity (neo-Islam Nusantara), or through certain tensions and conflicts that explain the discontinuity (contesting Islam Nusantara). Either its continuity or 
discontinuity has been significantly determined by diversity in terms of culture, social system and structures, and also politics. All of them as matters of diversity should not be understood as separated entities, but they are interrelated that have influenced the macro sociological process of Islam Nusantara itself via multiple layers of complexities. For example, political contestations always closely relate to social and cultural contexts. That is why the ideal concept of Bhinneka Tunggal Ika (unity in diversity) as the official national motto of Indonesia cannot really represent highly dynamics of both national and regional political contestations in the country. Reasons of this relative representation shows that the macro sociological process has its complexities. Thus, Islam Nusantara as a cultural manifestation of Islam is dynamic. Its dynamism has been conditioned by diversity through multiple complex ways and relations. Consequently, Islam Nusantara "relatively" can be understood as a representation of the ideal notion of Ummah.

How to explain its continuity and discontinuity? Nowadays, Islam Nusantara has been recognised as a better cultural manifestation of Islam in Indonesia rather than certain expressions that have been shown in Arab countries. At least, it has influenced societal developments which are relatively non-authoritarian, non-exclusive unilateralism, democratic, pro-human rights and human developments. These developments are dynamic and sometimes they need certain innovations in order to ensure the quality of adaptability. For example, as one of expressions of Islam Nusantara in the circle of modernist Muslim organisation, Muhammadiyah offers a concept of Indonesia as Negara Pancasila (a state of Pancasila) via the lens of Islamic intellectualism should be viewed as Där al'Ahd wa al-Shahädah (the state of agreement and witness). ${ }^{59}$ It means Indonesia

\footnotetext{
${ }^{59}$ See Din Syamsuddin, "NKRI: Negara Perjanjian dan Kesaksian," in Akhmad Sahal and Munawir Aziz (ed.), Islam Nusantara..., 278-286.
} 
should be recognised as the state that is essentially Islamic. In another circumstance, the dynamic nature of the process of micro sociological dimension of the tradition of Islam Nusantara shows its discontinuity. In the year of political contestation, it is obvious that religious discourse has not been free from many forms of political instrumentalisations. This discourse can be used as a tool of a political game. Spreading of criticism and rejections of Islam Nusantara for example, seems to explain a kind of its discontinuity in guarantying social bonds and cohesion. The case of a popular mass demonstration of Aksi Bela Islam (the action of supporting Islam) in Jakarta, highly likely indicates that the endurance of the continuity of Islam Nusantara is being tested. ${ }^{60}$ Hence, although the process of the constitution and development of Islam Nusantara is dynamic, and primarily it would be followed by possibilities of its discontinuity, its continuity - once again - should also be considered relatively as a sociological representation of the ideal notion of Ummah.

Therefore, although it is not easy to examine whether Islam Nusantara can be considered as a sociological representation of the ideal notion of Ummah or cannot, it as a dynamic tradition, through the micro sociological process of the constitution and development of tradition, widely has opened possibilities of becoming a kind of a representation. Accordingly, when one is asking question of what is exactly the sociological representation of the ideal notion of Ummah, in simple way, indeed, it can be answered, "Islam Nusantara".

${ }^{60}$ Greg Fealy, "Bigger than Ahok: Explaining the 2 December Mass Rally," Indonesia at Melbourne, The University of Melbourne, Australia, 7 December 2016. Retrieved from http://indonesiaatmelbourne.unimelb.edu.au/bigger-than-ahok-explaining-jakartas-2december-mass-rally/ (22 April 2018). 


\section{Concluding Remarks}

Generally, the concept of Ummah means 'the community of believers'. It is categorised either by societal, national or global boundaries, depends on the certain political interest amongst its agencies. It is contested both by Muslim intellectuals and Western scholars, but in the framework of the 'clash of civilisations' that diametrically perceives 'Islam' vis a vis 'the West'. It closes any possibility at making a progressive conceptualisation of Ummah. To reformulate a new insight of Ummah, this framework should be critically evaluated. It means, the concept of Ummah should be reinterpreted as a breakthrough of inter-civilisational dialogue that supported by humanitarian values such as liberalism, pluralism, democracy, human rights and sustainable development. It has been also enhanced by the availability of evidence that relatively explains that Islam Nusantara is one of sociological representations of the concept. In conclusion, the concept of Ummah should be understood as the modern concept of humanitarian solidarity that pervades beyond the various boundaries of identity, politics and territory.

\section{Bibliography}

Al-Maududi, A.A. Al-Khilāfah wa al-Mulk. Kuwait: Dār al-Qalam, 1978.

Asad, T. Genealogies of Religion: Discipline and Reasons of Power in Christianity and Islam. Baltimore; London: John Hopkins University Press, 1993. Ayubi, N. Over-Stating the Arab State: Politics and Society in the Middle East. London: New York: IB Tauris, 1995.

Bayat, A. Life as Politics: How Ordinary People Change the Middle East, Second Edition. Stanford, CA: Stanford University Press, 2013.

Bisri, M, "Sambutan: Islam Nusantara, Makhluk Apakah Itu?" in Akhmad Sahal and Munawir Aziz (ed.). Islam Nusantara: Dari Ushul Fiqh Hingga Konsep Historis. Bandung: Mizan, 2015: 13-14.

Brown, LC. International Politics and the Middle East: Old Rules, Dangerous Game. London: IB Tauris, 1984. 
Brykczynski, P., "Radical Islam and the Nation: The Relationship between Religion and Nationalism in the Political Thought of Hassan alBanna and Sayyid Qutb”, History of Intellectual Culture, vol. 5, no. 1 (2005): 1-19.

Burke, E., "Orientalism and World History: Representing Middle Eastern Nationalism and Islamism in the Twentieth Century", Theory and Society, vol. 27, no. 4 (1998): 489-507.

Doody, J.A., "Maclyntre and Habermas on Practical Reason", American Catholic Philosophical Quarterly, vol. 65, (1991): 143-158.

Elias, N. The Civilizing Process. Oxford: Blackwell, 1982.

Fealy, Greg, "Bigger than Ahok: Explaining the 2 December Mass Rally," Indonesia at Melbourne, The University of Melbourne, Australia, 7 December 2016. Retrieved from http://indonesiaatmelbourne. unimelb.edu.au/bigger-than-ahok-explaining-jakartas-2-decembermass-rally/ (22 April 2018).

Gesink, I.F., "Islamic Educational Reform in Nineteen Century-Egypt: Lessons for the Present," in Charlene Tan (ed.). Reforms in Islamic Education: International Perspectives. London: New York: Bloomsbury Academic, 2014: 17-34.

Gonggong, A. Menengok Sejarah Konstitusi Indonesia. Yogyakarta: Ombak dan Media Presindo, 2002.

Habermas, J. The Theory of Communicative Action, vol. 2, Lifeworld and System: A Critique of Functionalist Reason. Boston: Beacon Press, 1987. Hanafi, H., "From Orientalism to Occidentalism," Encounters in Language and Literature (2010): 407-414. Retrieved from http://www.fortschrittweltweit.de/dokumente/aegypten /fortschritt_aegypten_hanafi.pdf (14 September 2017).

Hanafi, H. Muqaddimah fĩ 'ilm al-Istighräb. Cairo: Dār al-Faniyyah, 1991.

Huntington, S. The Clash of Civilizations and the Remaking of World Order. New York: Simon and Schuster, 1996.

Ibrahim, A., "The Making of Progressive Religion," in Azhar Ibrahim and Mohamed Imran Mohamed Taib (eds.). Islam, Religion and Progress. Singapore: The Reading Group Singapore, 2006: 1-33.

Ibrahim, A. Contemporary Islamic Discourse in the Malay-Indonesian World: Critical Perspectives. Petaling Jaya: SIRD, 2014. 
IJIMS: Indonesian Journal of Islam and Muslim Societies, Volume 8, Number 1, June 2018: 87-116

Islam, Jamaat-e-Islami in Contemporary India and Bangladesh, Delhi: Cambridge University Press, 2015.

Kaloti, S.A. "The Reformation of Islam and the Impact of Afghani and Abduh on Islamic Education”, Doctoral Dissertation, Marquette University, Wisconsin, 1974

Karakoç, J. Authoritarianism in the Middle East: Before and After the Arab Uprisings. Hampshire: Palgrave Macmillan, 2015.

Khomeini. Islamic Government: Governance of the Jurist. Tehran: Institute for Compilation and Publication of Imam Khomeini's Work, 2002.

Lewis, B. What Went Wrong? Western Impact and Middle Eastern Response. New York: Oxford University Press, 2002.

Maarif, A.S. Islam dalam Bingkai Keindonesiaan dan Kemanusiaan: Sebuah Refleksi Sejarah. Bandung: Mizan, 2009.

Madjid, N., "Islamic Roots of Modern Pluralism: Indonesian Experience," Studia Islamika Journal of Islamic Studies, vol. 1, no. 1 (1994): 55-77.

Madjid, N. Cendekiawan dan Religiusitas Masyarakat. Jakarta: Pramadina, 1999.

Madjid, N. Demokrasi dan Demokratisasi. Jakarta: Paramadina, 1999.

Madjid, N. Islam, Doktrin dan Peradaban. Jakarta: Yayasan Waqaf Paramadina, 1992.

Madjid, N. The True Face of Islam: Essays on Islam and Modernity in Indonesia. Jakarta: Voice Center Indonesia, 2003.

Mandaville, P. Global Political Islam. London, New York: Routledge, 2007. Pankhurst, R. The Inevitable Caliphate?: A History of the Struggle for the Global Islamic Union. Oxford, New York: Oxford University Press, 2013.

Piscatori, J., "Imagining Pan-Islam," in Shahram Akbarzadeh and Fethi Mansouri (eds.). Islam and Political Violence. London, New York: IB Tauris, 2014: 27-38.

Piscatori, J., "Reinventing the Ummah? The Trans-locality of Pan-Islam," Lecture to the Tenth Anniversary Conference: Translocality: An Approach to Globalising Phenomena, Zentrum Moderner Orient, Berlin, 26 September 2006: 1-15.

Piscatori, J. Islam in a World of Nation-States. Cambridge: Cambridge University Press, 1986. 
Qutb, S. Ma'ālim fì al-Tāriq, Cairo: Dār al-Shurūq, 1979.

Ramadan, T. Radical Reform, Islamic Ethics and Liberation. Oxford; New York: Oxford University Press, 2009.

Ranko, A. The Muslim Brotherhood and its Quest for Hegemony in Egypt: State-

Discourse and Islamist Counter-Discourse. New York: Springer, 2015.

Roy, O. The Failure of Political Islam. London, New York: IB Tauris, 1994. Sahal, S and Aziz, M (ed.). Islam Nusantara: Dari Ushul Fiqh Hingga Konsep Historis. Bandung: Mizan, 2015.

Said, E.W. Covering Islam. London: Vintage, 2007.

Said, E.W. Culture and Imperialism. London: Vintage, 1994.

Said, E.W. Orientalism. London: Penguin Books, 2003.

Saikal, S., "Westphalian and Islamic Concepts of Sovereignty in the Middle East," in Sampford \& Thakur (eds.). Re-envisioning Sovereignty: the End of Westphalia? London: Ashgate, 2008: 73-81.

Salvatore, A., "Tradition and Modernity within Islamic Civilization and the West," in Muhammad Khalid Masud, Armando Salvatore and Martin van Bruinessen (eds.). Islam and Modernity: Key Issues and Debates. Edinburgh: Edinburgh University Press, 2009: 3-35.

Salvatore, A. The Public Sphere: Liberal Modernity, Catholicism, Islam. New York: Palgrave Macmilan, 2007.

Salvatore, A. The Sociology of Islam: Knowledge, Power and Civility. Malden, MA: Willey Blackwell, 2016.

Shahin, E.E., "The Foreign Policy of the Islamic Salvation Front in Algeria," Islam and Christian-Muslim Relations", vol. 14, no. 2 (2003): 121-143.

Syafruddin, A., "Manhaji: Betapa Indahnya Nusantara Kita, Bila..." and "Kajian Utama: Islam Nusantara," Asy-Syariah: Khazanah Ilmu-Ilmu Islam, vol. 10, no. 112 (2016): 5-11, 12-46.

Syamsuddin, D., "NKRI: Negara Perjanjian dan Kesaksian," in Akhmad Sahal and Munawir Aziz (ed.). Islam Nusantara: Dari Ushul Fiqh Hingga Konsep Historis. Bandung: Mizan, 2015: 278-286.

Tocqueville, A. Democracy in America. Indianapolis: Liberty Fund, 2010. Torres, C.A. Theoretical and Empirical Foundations of Critical Global Citizenship Education, London; New York: Routledge, 2017. 
IJIMS: Indonesian Journal of Islam and Muslim Societies, Volume 8, Number 1, June 2018: 87-116

Turner, B.S. Weber and Islam: A Critical Study. London: Routledge and Kegan Paul, 1974.

Wahid, A. Islamku, Islam Anda, Islam Kita: Agama Masyarakat Negara Demokrasi. Jakarta: The Wahid Institute, 2006.

Weber, M. The Protestant Ethic and the Spirit of Capitalism. London: Routledge, 2001.

Zubaida, S., "Islam and Nationalism: Continuities and Contradictions," Nations and Nationalism, vol. 10, no. 4 (2004): 407-420. 